\title{
Deficiency of magnesium in maize (Zea mays L.) induced by high potassium level in a micaceous soil of Kumaon region of Uttarakhand, India
}

\author{
Sovan Debnath", Raj Narayan, Anil Kumar, Brij Lal Attri and Arun Kishor \\ ICAR-Central Institute of Temperate Horticulture, Regional Station-Mukteshwar- 263138 (Uttarakhand), INDIA \\ *Corresponding author. E-mail: sovan.dta@gmail.com \\ Received: April 20,2015; Revised received:August 3, 2015 Accepted: November 5, 2015
}

\begin{abstract}
A field observation was undertaken in a farmer's field sown with maize at Mukteshwar, Uttarakhand to record whether $\mathrm{K}$ rich micaceous soil can cause $\mathrm{Mg}$ deficiency. The crop was fertilized with nitrogen and phosphorus only. The visible effect of Mg-deficiency initiated after 20-25 days of maize sowing as interveinal chlorosis in older leaves along the margins running the full length of the leaves parallel to the veins. In later stage, necrosis of older leaves occurred particularly at the tip of the leaves. The leaf and soil sample collected at 45 days after sowing (DAS) revealed an extremely low content of $\mathrm{Mg}$ in soil $\left(4.32 \mathrm{mg} \mathrm{kg}^{-1}\right)$ and plant $(0.11 \%)$. The soil analysis also revealed that the soil was acidic in nature ( $\mathrm{pH} 5.07)$ with low cation exchange capacity $\left(9.7 \mathrm{cmol} \mathrm{kg}^{-1}\right)$. However, the soil was having a very high level of water soluble $\left(18.2 \mathrm{mg} \mathrm{kg}^{-1}\right)$, exchangeable $\left(262.3 \mathrm{mg} \mathrm{kg}^{-1}\right)$ and available K $\left(280.5 \mathrm{mg} \mathrm{kg}^{-1}\right)$, which has resulted in an imbalanced exchangeable $\mathrm{K}: \mathrm{Mg}$ ratio $(60.7: 1)$ rendering reduced uptake of $\mathrm{Mg}$ by maize. Therefore, it was concluded from the study that magnesium deficiency can occur in maize in conditions like acidic, sandy, mica rich soils with high level of $\mathrm{K}$ combined with low $\mathrm{Mg}$ content, even without $\mathrm{K}$ fertilization. Hence, the farmers may use dolomitic lime and/or Mg-containing fertilizers to correct Mg deficiency under such conditions for sustainable agricultural production systems.
\end{abstract}

Keywords: Magnesium deficiency, Maize, Micaceous soil, Potassium

\section{INTRODUCTION}

Magnesium (Mg) is considered as secondary essential nutrient required by the crops and, is absorbed by crops as $\mathrm{Mg}^{+2}$ from the soil solution. The functions of $\mathrm{Mg}$ in crops are mainly related to its capacity to interact with strongly nucleophilic ligands (e.g., phosphoryl groups) through ionic bonding, and to act as a bridging element, and/or form complexes of different stabilities (Marschner, 1995). Most reactions involving phosphate transfer from adenosine tri-phosphate (ATP) require $\mathrm{Mg}$. Magnesium concentration in crops varies between 0.1 to $0.4 \%$ and, is a primary constituent of chlorophyll. Magnesium also serves as a structural component of ribosomes, stabilizing them in the configuration necessary for protein synthesis. Since the fundamental process of energy transfer occurs in photosynthesis, glycolysis, the citric acid cycle, and respiration, is important throughout crop metabolism (Havlin et al., 2009).

Magnesium deficiency in plants is a widespread problem, affecting productivity and quality in agriculture (Aitken et al., 1999). $\mathrm{Mg}^{+2}$ ions are more easily leached from the upper soil layers than $\mathrm{Ca}^{+2}$ because of less adsorption by soil colloids (Mengel et al., 2006). In addition, $\mathrm{Mg}$ is not specifically bound to clay minerals as in the case of $\mathrm{K}$. Therefore, it is highly prone to leaching, which is considered as one of the major factors in decreasing $\mathrm{Mg}$ availability for roots (Hermans et al., 2004). In many crops, Mg deficiency causes interveinal chlorosis in leaves, where only leaf veins remain green. Under severe $\mathrm{Mg}$ deficiency, leaf tissue becomes uniformly chlorotic to necrotic. Because of the mobility of $\mathrm{Mg}^{+2}$ in plants and its readily translocation from older to younger plant parts, deficiency symptoms often appear first on the lower leaves (Havlin et al., 2009).

Conditions in which $\mathrm{Mg}$ is likely to be deficient include acid, sandy, highly leached soil with low cation exchange capapcity (CEC), soils inherently low in $\mathrm{Mg}$ and, soils receiving high rates of $\mathrm{K}$ fertilization (Marschner, 1995; Havlin et al., 2009). Mg deficiency is also quite common in micaceous soils rich in $\mathrm{K}$ and consequently, $\mathrm{Mg}$ deficiency might be aggravated, particularly when $\mathrm{K}$ fertilizers are heavily applied as a result of antagonistic effect between $\mathrm{K}$ and $\mathrm{Mg}$ (Ding et al., 2006). This antagonism depends on soil type, physical properties, $\mathrm{pH}$, ambient temperature and moreover, proportion of the participating nutrients. Generally, the binding strengths of $\mathrm{K}$ and $\mathrm{Ca}$ to the exchange sites of clay minerals are much stronger than $\mathrm{Mg}$ and they easily out-compete $\mathrm{Mg}$ at exchange sites. Therefore, application of potassium fertilizers may reduce a plant's ability to absorb $\mathrm{Mg}$ (Ranade-Malvi, 2011). Non-judicious and imbalanced application of NPK fertilizers without $\mathrm{Mg}$ in high intensive agricul- 
tural cropping system has lead to a widespread deficiency of $\mathrm{Mg}$, especially in the light sandy acid soils of the world. Many researchers have reported deficiency of $\mathrm{Mg}$ in numerous crops caused by high $\mathrm{K}$ levels under $\mathrm{K}$ fertilization and/or combined application of $\mathrm{K}$ and $\mathrm{Mg}$. Nonetheless, there are very few developments in reporting the deficiency of $\mathrm{Mg}$ in maize grown without $\mathrm{K}$ fertilization in $\mathrm{K}$ rich micaceous soil of Kumaon region of Uttarakhand. Therefore, the objective of this study was to elucidate the effect of high level of soil $\mathrm{K}$ on the occurrence of $\mathrm{Mg}$ deficiency in maize grown in a mica rich soil of $\mathrm{Ku}-$ maon region, Uttarakhand. It is assumed that information generated from this study would help us in understanding the conditions conducive for the occurrence of $\mathrm{Mg}$ deficiency in this region.

\section{MATERIALS AND METHODS}

Study site, climate and soil: A field observation was undertaken in a farmer's field sown with maize at Mukteshwar, Nainital, Uttarakhand (latitude: $29^{\circ} 28^{\prime}$ $\mathrm{N}$, longitude: $79^{\circ} 39^{\prime} \mathrm{E}$; altitude: $2280 \mathrm{~m}$ above mean sea level). This site is located on a ridge at the southern edge of the Kumaon Hills of the Himalayan range. This area falls under temperate region, having hot and dry summer between May to June and cold and chilly conditions from November to February, with an average annual rainfall ranges from 1300-1600 mm, three-fourth of which is received during JulySeptember and the remaining one-fourth between October and June. Frequent snowfall occurs between December to February resulting in drop of minimum air temperature below freezing point. Annual maximum and minimum air temperature usually ranges between 25 to $-3{ }^{\circ} \mathrm{C}$, respectively. The soil of the site belongs to order Entisol (USDA Classification). The soil is loamy sand in texture, rich in mica, gravelly, deep and well drained with moderate permeability in the upper layer and rapid in the lower part. The soil is formed in a loamy mantle and sandy or gravelly sediments.

Agronomic management practices: Agricultural operations in this area are generally practiced under terrace condition with land slope greater than $30 \%$. The size of the terrace at the farmer's field was $100 \times 6$ $\mathrm{m}$ with net plot area of $10 \times 5 \mathrm{~m}$. Hybrid maize $(\mathrm{cv}$. Vivek 33) seeds were sown in mid June of 2014 with a spacing of $15 \mathrm{~cm}$ (intra-plant) $\times 30 \mathrm{~cm}$ (between-row). Soil was irrigated once before sowing to ensure adequate soil water for establishment of plants. A dose of $60 \mathrm{~kg} \mathrm{~N}$ $\mathrm{ha}^{-1}$ and $40 \mathrm{~kg} \mathrm{P}_{2} \mathrm{O}_{5} \mathrm{ha}^{-1}$ as basal was applied through urea and di-ammonium phosphate (DAP), respectively. No potassium fertilizer was added in the soil. Other recommended agronomic practices were also followed throughout experiment for raising the crop.

Leaf and soil sampling: About 25 days after sowing (DAS), older leaves of maize plants started showing stripped chlorosis symptom. About 45 DAS, older and younger leaves of the affected maize plants were

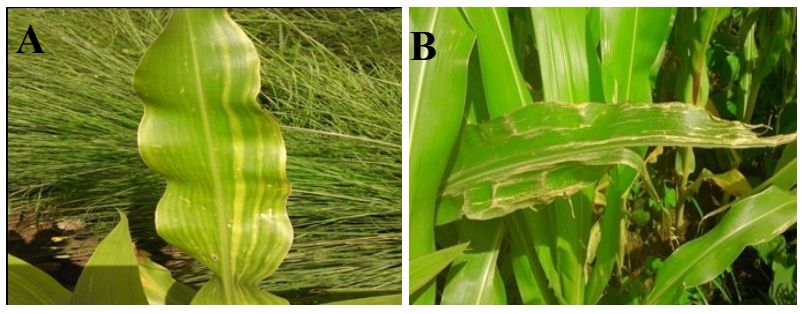

Fig. 1. Visual deficiency symptom of $\mathrm{Mg}$ in maize at (A) 30 days after sowing (yellow strips can be seen parallel to the veins) and (B) 45 days after sowing (older leaves with necrotic tip).

collected from those plots. The collected leaves were washed thoroughly with phosphate-free soap to remove waxes followed by rinsing with $0.1 \mathrm{~N} \mathrm{HCl}$ to remove possible contaminants and, finally rinsed with double distilled water to remove excess acid and, then dried at $70^{\circ} \mathrm{C}$ to constant weight. The nitrogen content in leaves was determined by micro-kjeldahl method (Singh et al., 2005). The leaves were also analyzed for phosphorus, potassium, calcium and magnesium contents by digestion with $\mathrm{HNO}_{3}: \mathrm{HClO}_{4}$ (4:1) mixture and, subsequent determination by vanadomolybdophosphoric acid, flame photometric method and versanate method, respectively (Bhargava and Raghupathi, 2001).

At the time of leaf sampling, soil samples were also collected randomly from the plots with the help of a screw auger from $0-15 \mathrm{~cm}$ depth. Soil samples were air dried, processed and sieved through $2 \mathrm{~mm}$ sieve and stored for further analytical purpose. The soil was analyzed for $\mathrm{pH}$ (1:2 soil to water suspension; Jackson, 1973), electrical conductivity (1:2 soil to water suspension; Bower and Wilcox, 1965), organic carbon (Walkley and Black, 1934), cation exchange capacity through NaOAc method (Jackson, 1973), available N (Subbiah and Asija, 1956), available P (Olsen et al., 1954) and exchangeable $\mathrm{Ca}$ and $\mathrm{Mg}$ (Jackson, 1973). The available $\mathrm{K}$ was extracted with $\mathrm{NH}_{4} \mathrm{OAc}$, $\mathrm{pH} 7.0$ (Schollenberger and Simon, 1945) and water soluble K was determined in the soil extracted with water (1:5:: soil: water) shaken for $5 \mathrm{~min}$. Exchangeable $\mathrm{K}$ was calculated by subtracting water soluble $\mathrm{K}$ from available $\mathrm{K}$.

\section{RESULTS AND DISCUSSION}

The present study indicated the visible effect of interveinal chlorosis which initiated 20-25 days after sowing of maize. The effect was seen first in the old leaves, initiated in the interveinal areas particularly along the margins, progressed towards the midribs and from the old towards the young leaves (Fig. 1A). Dead, round spots followed, which gave the impression of beaded streaking. Older leaves became reddish-purple, and the tips and edges became necrotic when the deficiency was severe (Fig. $1 \mathrm{~B}$ ). $\mathrm{Mg}^{+2}$ ions are mobile in the plant and deficiency always begins in the older leaves and the moves to the younger leaves as $\mathrm{Mg}^{+2}$ in phloem mobile and, translocated from older to younger leaves when supply is insufficient (Sawyer, 2004; 
Table 1. Physico-chemical properties of soil grown with maize.

\begin{tabular}{ll}
\hline Soil Parameter $(\mathbf{s})$ & Value \\
\hline $\mathrm{pH}(1: 2(\mathrm{w} / \mathrm{v})$ soil to water suspension) & 5.07 \\
Electrical conductivity $\left(\mathrm{dS} \mathrm{m}^{-1}\right)$ & 0.08 \\
$(1: 2(\mathrm{w} / \mathrm{v})$ soil to water suspension) & \\
Organic $\mathrm{C}\left(\mathrm{g} \mathrm{kg}^{-1}\right)$ & 7.10 \\
Organic matter $\left(\mathrm{g} \mathrm{kg}^{-1}\right)^{*}$ & 12.20 \\
Cation exchange capacity $\left(\mathrm{cmol} \mathrm{P}^{+} \mathrm{kg}^{-1}\right)$ & 9.72 \\
Available $\mathrm{N}\left(\mathrm{mg} \mathrm{kg}^{-1}\right)$ & 87.40 \\
Available $\mathrm{P}\left(\mathrm{mg} \mathrm{kg}^{-1}\right)$ & 7.85 \\
Available $\mathrm{K}\left(\mathrm{mg} \mathrm{kg}^{-1}\right)$ & 280.50 \\
Water soluble K $\left(\mathrm{mg} \mathrm{kg}^{-1}\right)$ & 18.20 \\
Exchangeable K $\left(\mathrm{mg} \mathrm{kg}^{-1}\right)$ & 262.30 \\
Exchangeable Ca $\left(\mathrm{mg} \mathrm{kg}^{-1}\right)$ & 14.00 \\
Exchangeable $\mathrm{Mg}\left(\mathrm{mg} \mathrm{kg}^{-1}\right)$ & 4.32 \\
\hline
\end{tabular}

*Organic $\mathrm{C}(\mathrm{OC})$ data were converted to organic matter $(\mathrm{OM})$ using the conventional conversion $\mathrm{OM}=\mathrm{OC} \times 1.724$.

Mengel et al., 2006). Under Mg deficiency, necrosis of older leaves occurs particularly at the tips of the leaf, which was the case in this study also. Sawyer (2004) observed magnesium deficiency first seen as yellow to white interveinal striping of the lower corn leaves and eventually, the older leaves became reddish-purple with necrotic tips. Magnesium deficiency symptoms differ between plant species although some general characteristics like interveinal yellowing or chlorosis are apparent and necrosis occurs, particularly at the tip of the leaf (Marschner, 1995; Mengel et al., 2006; Havlin et al., 2009). Recently, Bing et al. (2011) also reported that the deficiency of magnesium appears as yellow or white strips in lower leaves of maize plants, running the full length of the leaves parallel to the veins. In later stage, the stripping turned into dead and round spots appearing as beaded streaks. Similar kind of observation was also made in this study and therefore, it confirms the deficiency symptom of magnesium in maize as described by these authors. The older leaves eventually dried and withered leading to stunted growth of the crop.

The soil analysis revealed that it was acidic in nature (pH 5.07) with low cation exchange capacity $(9.7 \mathrm{cmol}$ $\mathrm{kg}^{-1}$ ), low in $\mathrm{Mg}$ content (4.32 $\mathrm{mg} \mathrm{kg}^{-1}$ ) and high in $\mathrm{K}$ $\left(280.5 \mathrm{mg} \mathrm{kg}^{-1}\right.$ ) availability (Table 1). The water soluble $\mathrm{K}$ content of soil was also quite high $(18.2 \mathrm{mg}$ $\mathrm{kg}^{-1}$ ). Generally, the water soluble $\mathrm{K}$ content for optimum plant growth varies between 1 to $10 \mathrm{mg} \mathrm{kg}^{-1}$ (Havlin et al., 2009). The exchangeable Mg level (4.32 $\mathrm{mg} \mathrm{kg}^{-1}$ ) of the soil was in extremely deficient range.
Generally, soils are likely to be deficient in $\mathrm{Mg}$ when they contain less than $25 \mathrm{mg} \mathrm{kg}^{-1}$ exchangeable $\mathrm{Mg}$ (MAAF, 1979; Havlin et al., 2009). In this study, exchangeable soil $\mathrm{Mg}$ level was extremely low as compared to the critical level. Low cation exchange capacity of the soil has led to the reduced adsorption of exchangeable $\mathrm{Mg}$ to the exchange sites resulting leaching of $\mathrm{Mg}^{+2}$ ions to subsoil. Loss of $\mathrm{Mg}$ by leaching predominates frequently on sandy soils. In such soils the subsoil often contains higher levels of $\mathrm{Mg}$ than in the upper layer of the soil profile. This was perhaps one of the major reasons for $\mathrm{Mg}$ deficiency in maize. Cation competitions in soil may play a crucial role and the uptake of $\mathrm{Mg}$ can be greatly depressed by an excess of other cation species, especially of $\mathrm{K}$ which are absorbed at high rates and, may compete with $\mathrm{Mg}$ for the negatively charged cytosol (Mengel et al., 2006). This competition can lead to $\mathrm{Mg}$ deficiency in plants. Generally, the recommended exchangeable K: $\mathrm{Mg}$ ratio for field crops is 5:1 (Havlin et al., 2009) however, the observed ratio was 60.7:1 in this study (Table 2). Therefore, it is clear from the results that the soil physico-chemical conditions were extremely conducive for $\mathrm{Mg}$ deficiency to occur.

The imbalanced $\mathrm{K}$ and $\mathrm{Mg}$ levels of the soil have also disrupted the uptake of $\mathrm{Mg}$ by maize as indicated by leaf $\mathrm{Mg}$ concentrations. The $\mathrm{Mg}$ concentrations in younger and older leaves $(0.14$ and $0.11 \%$, respectively) were also low (Table 2), which is categorized as deficient range (Marschner, 1995). A decrease in the older leaves compared to the younger leaves in the concentration of $\mathrm{Mg}$ corroborates the relative severity of Mg-deficiency effects in the older leaves. Generally, maize is considered as an exhaustive crop and the demand for nutrients remains higher for this crop. With the level of $\mathrm{Mg}$ in soil, the uptake of $\mathrm{Mg}$ was probably suboptimal and moreover, increased uptake of $\mathrm{K}$ also led an antagonistic effect on $\mathrm{Mg}$ uptake by plant roots. Not only the uptake but also the physiological translocation of $\mathrm{Mg}$ from the roots to the upper plant parts can be restricted by high level of soil K (Marschner, 1995). Antagonism between two mineral nutrients becomes even more important when the content of one of the elements is near in deficiency range (Ranade-Malvi, 2011). In this case, it was $\mathrm{Mg}$ which was in deficient range, whereas, $\mathrm{K}$ was present in excessive range. The plants became stunted and have an overall yellow appearance in the later stage of growth. Although the data regarding yield was not recorded in this particular study, the farmers have

Table 2. Nutrient content in leaves and ratio of exchangeable $\mathrm{K}, \mathrm{Ca}$ and $\mathrm{Mg}$ in soil and leaves of maize.

\begin{tabular}{llllcl}
\hline Nutrient Content & Younger leaves & Older leaves & Ratio of nutrient & Soil & Leaves* \\
\hline $\mathrm{N}(\%)$ & 3.97 & 3.83 & $\mathrm{~K}: \mathrm{Mg}$ & 60.70 & 24.13 \\
$\mathrm{P}(\%)$ & 0.38 & 0.31 & $\mathrm{~K}: \mathrm{Ca}$ & 18.60 & 13.47 \\
$\mathrm{~K}(\%)$ & 3.00 & 2.95 & $\mathrm{Ca}: \mathrm{Mg}$ & 3.25 & 1.85 \\
$\mathrm{Ca}(\%)$ & 0.20 & 0.25 & & & \\
$\mathrm{Mg}(\%)$ & 0.14 & 0.11 & & & \\
\hline
\end{tabular}

*Average of younger and older leaves 
observed $50-60 \%$ yield decline compared to his expectation. According to the farmers, the grains formed were also shriveled, malformed and not suitable for consumption.

\section{Conclusion}

It was seen that when uptake of nutrients is concerned, the crops could preferentially exclude or absorb nutrients based on the concentration of nutrients provided to them and, any odd combination of nutrients is unable to provide the essential nutrients in the appropriate ratios required by the crop. It was observed that high $\mathrm{K}\left(280.5 \mathrm{mg} \mathrm{kg}^{-1}\right.$ ) and low $\mathrm{Mg}$ content (4.32 mg $\left.\mathrm{kg}^{-1}\right)$ of soil has resulted an imbalanced ratio $(60.7: 1)$ which rendered reduced uptake and translocation of $\mathrm{Mg}$ causing its deficiency in maize. Therefore, conditions like acidic, sandy, mica rich soils with high level of $\mathrm{K}$ and low CEC could lead to $\mathrm{Mg}$ deficiency in crops like maize, even without $\mathrm{K}$ fertilization. The condition may further aggravate when soils are heavily fertilized with NPK without Mg. Periodical soil tests can help detect $\mathrm{Mg}$ deficiency in crops. Thus, the farmers are urged to use dolomitic lime and/or Mg- containing fertilizers to alleviate the conditions causing Mg deficiency for sustainable agricultural production systems in this area.

\section{ACKNOWLEDGEMENTS}

We want to thank Prof. Nazeer Ahmed, Director, ICAR-CITH for providing the facilities to conduct this research. Thanks to the anonymous reviewer for his critical remarks and valuable suggestions regarding improvement of the manuscript.

\section{REFERENCES}

Aitken, R. L., Dickson, T., Hailes, K. J. and Moody, P. W. (1999). Response of field-grown maize to applied magnesium in acidic soil in north eastern Australia. Aus. $J$. Agric. Res. 50: 191-198.

Bhargava, B. S. and Raghupathi, H. B. (2001). Analysis of plant materials for macro and micronutrients. Methods of Analysis of Soils, Plants, Waters and Fertiliser. FDCO, New Delhi, pp 49-82.

Bing, Y., Ketterings, Q., Czymmek, K., Albers, C., Heredeen, N. and Mikkelsen, R. (2011). Magnesium for field crops. Agronomy Fact Sheet Series 59. Cornell Univer- sity Cooperative Extension. Cornell University, USA.

Bower, C. A. and Wilcox, L. V. (1965). Soluble salts. Methods of Soil Analysis, ASA Inc., Madison, Wisconsin, USA, pp 433-451.

Ding, Y., Luo, W. and Xu, G. (2006). Characterization of magnesium nutrition and interaction of magnesium and potassium in rice. Ann. Appl. Biol. 149: 111-123.

Havlin, J. L., Beaton, J. D., Tisdale, S. L. and Nelson, W. L. (2009). Soil Fertility and Fertilizers- An Introduction to Nutrient Management. PHI Learning Pvt. Ltd., New Delhi.

Hermans, C., Johnson, G. N., Sstsrasser, R. J. and Verbruggen, M. (2004). Physiological characterization of magnesium deficiency in sugar beet: acclimation to low magnesium differentially affects photosystems I and II. Planta 220: 344-355.

Jackson, M. L. (1973). Soil Chemical Analysis. Prentice Hall, New Delhi.

M.A.A.F. (1979). Ministry of Agriculture, Fisheries and Food, Fertilizer Recommendations. London, United Kingdom.

Marschner, H. (1995). Mineral Nutrition of Higher Plants. Academic Press, London.

Mengel, K., Kirkby, E. A., Kosegarten, H. and Appel, T. (2006). Principles of Plant Nutrition. Springer (India) Pvt. Ltd. New Delhi.

Ranade-Malvi, U. (2011). Interaction of micronutrients with major nutrients with special reference to potassium. Karnataka J. Agric. Sci. 24: 106-109.

Olsen, S. R., Cole, C., Watanbe, F. S. and Dean, L. A. (1954). Estimation of available phosphorus in soils by extraction with sodium bicarbonate. Circular U.S. Dept. Agric. pp. 939.

Sawyer, J. (2004). Nutrient deficiencies and application injuries in field crops. IPM 42. Iowa State University Cooperative Extension. Iowa State University of Science and Technology, Iowa, USA.

Schollenberger, C. J. and Simon, R. H. (1945). Determination of exchange capacity and exchangeable bases in soil - ammonium acetate method. Soil Sc. 59: 13-24.

Singh, D., Chhonkar, P. K. and Dwivedi, B. S. (2005). Manual on Soil, Plant and Water Analysis. Westville Publishing House, New Delhi.

Subbiah, B. V. and Asija, G. L. (1956). A rapid procedure for the determination of available nitrogen in soils. Curr. Sci. 25: 259-260.

Walkley, A. H. and Black, I. A. (1934). Estimation of soil organic carbon by the chromic acid titration methods. Soil Sci. 37: 29-38. 